\title{
Minuman Kedelai (Glycine max) dan Kombinasi Asam Jawa (Tamarindus indica) dengan Kunyit (Curcuma domestica) dalam Mengurangi Nyeri Haid
}

Claudia Anggie Anugrahhayyu*, Ninik Darsini, Ashon Sa'adi

Program Studi Pendidikan Bidan, Fakultas Kedokteran, Universitas Airlangga, Surabaya

*Corresponding author: claudia.anggie.anugrahhayyu-2014@fk.unair.ac.id

\begin{abstract}
Background: Dysmenorrhea can be experienced by some women with abdominal pain before or during menstruation period. Symptoms of dysmenorrhea come pain which radiates backwards for 8 to 72 hours. Objective: This study aimed to identify the influence if soybean (Glycine max) and tamarind (Tamarindus indica) combine with turmeric (Curcuma domestica) on the scale of pain due to dysmenorrhea for female students in SMK Farmasi Sekesal Surabaya. Methods: The method used in this study was experimental with quasi experimental pretest and posttest study design. The total sample is 27 female students aged $15-18$ years taken by purposive sampling divided into three groups, each group consisted of 9 respondents. The three groups consisted of groups using soybean (Glycine max), the tamarind (Tamarindus indica) group combine with turmeric (Curcuma domestica) and mefenamic acid as the control group. The Wilcoxon Sign Rank Test, The Kruskal Wallis Test and The Mann Whitney U Test were conducted to examine the differences of the three groups of respondents. Results: The result showed that there were significant differences in the administrations of soybean (Glycine max) and the combination of tamarind (Tamarindus indica) with turmeric (Curcuma domestica) on the scale of pain due to dysmenorrhea for female students in SMK Farmasi Sekesal Surabaya. Conclusion: In conclusion is the combination of tamarind (Tamarindus indica) and turmeric (Curcuma domestica) is more effective in reducing the scale of pain due to dysmenorrhea for female students in SMK Farmasi Sekesal Surabaya.
\end{abstract}

Keywords: dysmenorrhoea, turmeric, tamarind, soybean

\begin{abstract}
Abstrak
Pendahuluan: Beberapa wanita ketika mentruasi dengan nyeri perut baik sebelum menstruasi atau selama menstruasi itu disebut dismenorea. Gejala dismenorea seperti rasa sakit yang memancar ke belakang dengan durasi rasa sakit kurang lebih selama 8 hingga 72 jam. Tujuan: Penelitian ini bertujuan untuk mempelajari seberapa besar pengaruh kedelai (Glycine max) dan kombinasi asam jawa (Tamarindus indica) dengan kunyit (Curcuma domestica) dalam mengurangi skala nyeri dismenorea siswi di SMK Farmasi Sekesal Surabaya. Metode: Penelitian ini merupakan penelitian eksperimental dengan Quasy experimental pretest and posttest design. Total sampel 27 siswi termasuk usia 15 - 18 tahun sesuai dengan kriteria inklusi. Pengambilan sampel dilakukan dengan purposive sampling. Variabel bebasnya adalah asam jawa (Tamarindus indica), kunyit (Curcuma domestica), dan kedelai (Glycine max), sedangkan variabel dependennya adalah nyeri dismenorea. Mengetahui tingkat signifikan, data yang terkumpul dari total $\quad 27$ responden masing-masing 9 responden pada tiap kelompok dan hasilnya akan diuji dengan uji statistik uji Wilcoxon Sign Rank Test, Kruskal Wallis Test dan Mann Whitney U Test pada taraf signifikan $\alpha=0,05$. Hasil: Hasil penelitian menunjukkan bahwa ada perbedaan bermakna pada pemberian kedelai (Glycine max) dan kombinasi asam jawa (Tamarindus indica) dengan kunyit (Curcuma domestica) terhadap skala nyeri dismenorea siswi di SMK Sekesal Surabaya. Kesimpulan: Minuman kombinasi asam jawa (Tamarindus indica) dengan kunyit (Curcuma domestica) semakin menurunkan skala nyeri dismenorea dibandingkan dengan minuman kedelai (Glycine max) pada siswa remaja di SMK Farmasi Sekesal Surabaya.
\end{abstract}

Kata kunci: dismenorea, kunyit, asam jawa, kedelai 


\section{PENDAHULUAN}

Pada sebagian wanita yang menstruasi mengalami rasa nyeri pada bagian abdomen baik saat menjelang menstruasi maupun saat menstruasi, hal ini dinamakan dismenorea. Gejala dismenorea yaitu seperti nyeri yang menjalar hingga ke bagian punggung dengan durasi nyeri kurang lebih selama 8 sampai 72 jam. Menurut International Association for Study of Pain (IASP) nyeri adalah sensori subyektif dan emosional yang tidak menyenangkan yang didapat terkait dengan kerusakan jaringan aktual maupun potensial.

Penanganan nyeri secara farmakologi dapat diberikan SPO (Standard Procedure Operasional), yaitu diberikan anti nyeri seperti obat-obatan analgesik, obat hormonal dan obat NSAID (Non-Steroidal AntiInflammatory Drug) (Smith \& Kaunitz, 2015). Penanganan nyeri dismenorea secara herbal dapat kita berikan jamu-jamuan berbahan dasar kunyit, asam jawa, jahe dan susu kedelai (Noorafshan, 2012). Saat ini pada zaman yang semakin maju penderita nyeri dismenorea mulai memilih obat-obatan herbal khususnya dalam menangani nyeri karena dismenorea. Beberapa bahan untuk obat herbal yang memiliki manfaat dalam menangani nyeri perut akibat nyeri dismenorea antara lain seperti kedelai (Glycine max), asam jawa (Tamarindus indica) dan kunyit (Curcuma domestica) (Noorafshan, 2012).

Kedelai (Glycine max) dipercaya mampu meringankan nyeri dismenorea. Kalsium yang terkandung didalamnya membantu menghilangkan kecemasan, mengendalikan konduksi impuls saraf ke otak dan dari otak kekurangan kalsium dapat menyebabkan kekejangan otot. Kandungan estrogen yang terdapat pada kedelai (Glycine max) juga dapat membantu penyerapan kalsium. Konsumsi diet 60 gram protein kedelai (Glycine max) setiap hari dapat meningkatkan fase folikuller dan efek ini dihubungkan juga dengan penindasan lonjakan midcycle FSH (Follicle Stimulating Hormone) dan LH (Luteinizing Hormone) (Anugroho \& Ari, 2011).

Asam jawa (Tamarindus indica) memiliki zat berkhasiat antosianin yang paling bermanfaat sebagai anti inflamasi dan antipiretik dalam menangani nyeri dismenorea. Karena antosianin pada buah asam jawa ini dapat bekerja dengan cara menghambat kerja cyclooxygenase/COX untuk menghambat pelepasan prostaglandin sebagai penyebab dismenorea (Caluwe dkk., 2010). Asam jawa (Tamarindus indica) diduga dapat menurunkan kontraksi otot polos dengan memblok kanal kalsium serta menghambat pengeluaran kalsium intrasel dari retikulum sarkoplasma.
Mekanisme ini dilakukan oleh flavonoid, tannin, dan magnesium yang terkandung di dalamnya (Blackburn \& Jane, 2014).

Kunyit (Curcuma domestica) memiliki efek dalam membantu melancarkan darah menstruasi, menghilangkan sumbatan dalam peredaran darah, meluruhkan darah menstruasi, sebagai anti inflamasi, karminativa, kolagoga, anti bakteri dan sebagai astringensia. Zat berkhasiat kunyit (Curcuma domestica) yang dapat berperan sebagai anti inflamasi adalah kurkumin (Jurenka, 2009). Kurkumin bekerja dengan menghambat enzim cyclooxigenase-2/COX-2 memproduksi prostaglandin secara berlebih (Anindita, 2010).

Tujuan dari penelitian ini adalah mengetahui skala nyeri dismenorea sebelum dan sesudah pemberian terapi kedelai (Glycine max) dan kombinasi kunyit (Curcuma domestica) dengan asam jawa (Tamarindus indica) yang kemudian dibandingkan lebih efektif antara kedua terapi tersebut selain SPO (Standard Procedure Operasional) terapi anti nyeri yaitu asam mefenamat.

\section{METODE}

\section{Tempat penelitian}

Tempat penelitian ini dilakukan di SMK Farmasi Sekesal Surabaya.

\section{Desain penelitian}

Desain penelitian menggunakan Quasy experimental pretest and posttest design. Populasi yang digunakan pada penelitian ini adalah siswi SMK Farmasi Sekesal Surabaya yang mengalami nyeri haid atau dismenorea. Pada penelitian ini siswi yang memenuhi kriteria dibagi menjadi 3 kelompok yaitu kelompok kedelai/SD, kelompok kombinasi asam jawa-kunyit/KA dan kelompok asam mefenamat/SPO.

\section{Teknik sampling penelitian}

Teknik sampling dalam penelitian ini adalah purposive sampling, yaitu suatu pengambilan sampling yang dilakukan berdasarkan keputusan peneliti. Jadi pengambilan sampling yang menurut peneliti sesuai dengan kriteria inklusi dan eksklusi peneliti. Sampel dalam penelitian ini terdapat 3 kelompok dan masingmasing kelompok diisi sebanyak 9 siswi pada setiap kelompok dengan skala nyeri yang bervariasi.

Kelompok pertama yaitu SD, diberikan terapi susu kedelai sebanyak $350 \mathrm{~mL}$ yang mengandung 411,6 mg kalsium dengan aturan mengkonsumsi sekali minum pada saat keluhan sakit dirasakan kemudian dievaluasi 1 jam setelahnya. Kelompok kedua yaitu KA, diberikan terapi minuman kombinasi kunyit asam $350 \mathrm{~mL}$ yang 
mengandung asam jawa basah 80 gram, kunyit segar 150 gram, gula jawa 130 gram dan gula pasir 80 gram. Kunyit basah yang dirajang tipis kemudian dikeringkan dengan cara dijemur kurang lebih 2 sampai 3 hari dibawah sinar matahari yang diberi alas kain hitam sebagai metode penyerap panas. Semua bahan baku yang sudah diracik direbus sendiri oleh peneliti. Kelompok ketiga yaitu SPO atau disebut sebagai kelompok kontrol tetapi diberikan asam mefenamat $500 \mathrm{mg}$.

\section{Pengumpulan data}

Pengumpulan data dikumpulkan menggunakan instrumen penelitian berupa lembar pengumpulan data yang berisi lembar skala nyeri (Numeric Rating Scale dan Face Scale). Kriteria inklusi dalam penelitian ini adalah:

1. Wanita usia 15 sampai 20 tahun

2. Telah mengalami menstruasi

3. Siklus menstruasi normal tiap bulan (3 bulan terakhir)

4. Mengalami dismenorea

Setiap kelompok diobservasi skala nyeri saat dismenorea. Pada saat siswi mengalami dismenorea peneliti langsung memberikan terapi. Terapi tersebut diberikan sesuai dengan kelompoknya kemudian diobservasi kembali skala nyeri nya 1 jam setelah mengkonsumsi terapi tersebut. Dosis terapi minuman kedelai dan minuman kombinasi asam jawa dengan kunyit masing-masing sebanyak $350 \mathrm{~mL}$ diberikan 1 kali pada saat siswi dismenorea. Terapi asam mefenamat peneliti menggunakan dosis $500 \mathrm{mg}$ sesuai SPO anti nyeri. Pada saat siswi mengalami dismenorea jelas di waktu yang berbeda-beda, sehingga peneliti harus memberikan terapi di waktu yang tidak menentu.

Analisis data pada penelitian ini menggunakan uji Wilcoxon Sign Rank Test, Kruskal Wallis Test dan Mann Whitney untuk mengetahui perbandingan:

1) Sebelum dan sesudah pemberian minuman kedelai terhadap dismenorea.

2) Sebelum dan sesudah pemberian minuman kombinasi asam jawa dengan kunyit terhadap dismenorea.

\section{HASIL DAN PEMBAHASAN}

Pada siswi SMK Farmasi Sekesal Surabaya yang mengalami dismenorea yang telah diukur sendiri oleh siswi tersebut menggunakan lembar Numeric Rating Scale dan Face Scale kemudian didapatkan hasil sebelum dan sesudah diberikan terapi untuk diperbandingkan seperti Tabel 1 berikut.

Tabel 1. Skala nyeri tiap kelompok sebelum dan sesudah pemberian terapi

\begin{tabular}{|c|c|c|c|c|c|c|c|c|c|c|c|c|}
\hline \multirow{4}{*}{ Karakteristik } & \multicolumn{12}{|c|}{ Kelompok } \\
\hline & \multicolumn{4}{|c|}{ Kedelai } & \multicolumn{4}{|c|}{ Asam jawa + kunyit } & \multicolumn{4}{|c|}{ Asam mefenamat } \\
\hline & \multicolumn{2}{|c|}{ sebelum } & \multicolumn{2}{|c|}{ sesudah } & \multicolumn{2}{|c|}{ sebelum } & \multicolumn{2}{|c|}{ sesudah } & \multicolumn{2}{|c|}{ sebelum } & \multicolumn{2}{|c|}{ sesudah } \\
\hline & $\mathrm{n}$ & $\%$ & $\mathrm{n}$ & $\%$ & $\mathrm{n}$ & $\%$ & $\mathrm{n}$ & $\%$ & $\mathrm{n}$ & $\%$ & $\mathrm{n}$ & $\%$ \\
\hline Tanpa nyeri & - & - & 1 & 11,1 & - & - & 8 & 88,9 & - & - & 8 & 88,9 \\
\hline Nyeri ringan & 3 & 33,3 & 8 & 88,9 & 3 & 33,3 & 1 & 11,1 & 3 & 33,3 & 1 & 11,1 \\
\hline Nyeri sedang & 5 & 55,6 & - & - & 5 & 55,6 & - & - & 6 & 66,7 & - & - \\
\hline Nyeri berat & 1 & 11,1 & - & - & 1 & 11,1 & - & - & - & - & - & - \\
\hline Total & 9 & 100 & 9 & 100 & 9 & 100 & 9 & 100 & 9 & 100 & 9 & 100 \\
\hline
\end{tabular}

Pada Tabel 1 diketahui skala nyeri dismenorea pada siswi di SMK Farmasi Sekesal Surabaya sebelum diberikan terapi kedelai (Glycine max) sebagian besar siswi mengalami nyeri sedang (skala 2 pada Numeric Rating Scale), saat sesudah diberikan terapi kedelai (Glycine max) sebagian besar siswi mengalami nyeri ringan (skala 1 pada Numeric Rating Scale). Berdasarkan uji statistik Wilcoxon Signed Ranks Test didapatkan hasil $\mathrm{p}=0,023$ dimana $\mathrm{p}<0,05$ artinya ada beda signifikan antara sebelum dan sesudah pemberian kedelai terhadap skala nyeri pada dismenorea siswi di SMK Farmasi Sekesal Surabaya.

Pada kelompok terapi kombinasi asam jawa ( $T$. indica) dan kunyit ( $C$. domestica) sebelum diberikan terapi sebagian besar siswi mengalami nyeri sedang (skala 2 pada Numeric Rating Scale), saat sesudah diberikan terapi nyeri sebagian besar siswi menjadi tanpa nyeri (skala 0 pada Numeric Rating Scale). Berdasarkan uji statistik Wilcoxon Signed Ranks Test didapatkan hasil $\mathrm{p}=0,006$ dimana $\mathrm{p}<0,05$ artinya ada beda signifikan antara sebelum dan sesudah pemberian kombinasi asam jawa ( $T$. indica) dengan kunyit ( $C$. domestica) terhadap skala nyeri pada dismenorea siswi di SMK Farmasi Sekesal Surabaya.

Pada kelompok asam mefenamat sebelum diberikan terapi sebagian besar siswi mengalami nyeri sedang (skala 2 pada Numeric Rating Scale), saat sesudah diberikan terapi nyeri sebagian besar siswi menjadi tanpa nyeri (skala 0 pada Numeric Rating Scale). Berdasarkan uji statistik Wilcoxon Signed 
Ranks Test didapatkan hasil $\mathrm{p}=0,006$ dimana $\mathrm{p}<0,05$ artinya ada beda signifikan antara sebelum dan sesudah pemberian asam mefenamat terhadap penurunan skala nyeri pada dismenorea siswi di SMK Farmasi Sekesal Surabaya.

Tabel 2. Perbandingan skala nyeri dismenorea siswi pada tiap kelompok terapi

\begin{tabular}{ccccccc}
\hline & Jumlah & $\begin{array}{c}\text { Mean } \\
\text { Rank }\end{array}$ & p value & U & W & Z \\
\cline { 2 - 7 } Kedelai & 9 & 13,00 & 0,001 & 9,000 & 54,000 & $-3,207$ \\
Kunyit Asam & 9 & 6,00 & & & & \\
\hline TOTAL & 18 & & & & & \\
\hline
\end{tabular}

Berdasarkan uji statistik Mann-Whitney Test pada Tabel 2, didapatkan hasil bahwa nilai U sebesar 9 dan nilai $\mathrm{W}$ sebesar 54. Apabila dikonversikan ke nilai $\mathrm{Z}$ maka besarnya $-3,207$. Nilai Sig atau p value sebesar $0,001<0,05$. Apabila nilai $\mathrm{p}$ value $<$ batas kritis 0,05 maka terdapat perbedaan bermakna antara kelompok kedelai (Glycine max) dan kelompok kombinasi asam jawa (Tamarindus indica) dengan kunyit (Curcuma domestica).

Hasil penelitian ini menunjukan bahwa kelompok kombinasi asam jawa ( $T$. indica) dengan kunyit $(C$. domestica) dan kelompok asam mefenamat terdapat perbedaan yang bermakna apabila dibandingkan dengan kelompok kedelai (Glycine max). Kombinasi asam jawa (Tamarindus indica) dengan kunyit (Curcuma domestica) lebih menurunkan dismenorea dibandingkan kelompok kedelai (Glycine max) pada siswi remaja di SMK Farmasi Sekesal Surabaya. Berdasarkan uji statistik Wilcoxon Sign Rank Test, Kruskall Wallis dan Mann Whitney U Test diperoleh nilai sebagai berikut:

1. Ada perbedaan yang signifikan terhadap dismenorea antara sebelum dan sesudah pemberian kedelai (Glycine max) pada siswi di SMK Farmasi Sekesal Surabaya $(\mathrm{p}=0,023)$.

Berdasarkan penelitian tersebut peneliti berasumsi bahwa terapi susu kedelai sebanyak $350 \mathrm{~mL}$ yang mengandung 411,6 mg kalsium terbukti efektif dalam menurunkan nyeri haid. Hasil penelitian ini sejalan dengan penelitian sebelumnya oleh Budiarti \& Rizta (2015) tentang efektivitas pemberian terapi susu kedelai terhadap penurunan skala nyeri haid atau dismenorea pada remaja putri di Pondok Pesantren Al-Jihad Surabaya $(\mathrm{p}=0,005)$.

2. Ada perbedaan yang signifikan terhadap dismenorea antara sebelum dan sesudah pemberian kombinasi asam jawa ( $T$. indica) dengan kunyit ( $C$. domestica) pada siswi di SMK Farmasi Sekesal Surabaya $(\mathrm{p}=0,006)$.
Berdasarkan penelitian tersebut dapat disimpulkan bahwa minuman kombinasi asam jawa dan kunyit efektif dalam menurunkan nyeri haid. Hasil penelitian ini sejalan dengan penelitian oleh Astuti (2016) tentang pengaruh vitamin B1 dan kunyit terhadap dismenorea dan Marlina (2012) tentang kunyit berpengaruh dalam menurunkan nyeri dismenorea primer di SMK Tanjung $(\mathrm{p}=0,000)$.

3. Ada perbedaan yang signifikan terhadap skala nyeri dismenorea yang diberi kedelai (Glycine max) dan kombinasi asam jawa ( $T$. indica) dengan kunyit $(C$. domestica) pada siswi di SMK Farmasi Sekesal Surabaya $(\mathrm{p}=0,001)$.

Berdasarkan penelitian tersebut dapat disimpulkan bahwa minuman susu kedelai dan kombinasi asam jawa dengan kunyit efektif dalam menurunkan nyeri haid. Tetapi minuman kombinasi asam jawa dengan kunyit lebih menurunkan skala nyeri dismenorea dibandingkan minuman susu kedelai pada siswi remaja di SMK Farmasi Sekesal Surabaya. Minuman kombinasi asam jawa kunyit dapat menjadi alternatif pilihan dalam meringankan nyeri haid apabila penderita tidak ingin minum obat-obat medis untuk meringankan nyeri haid dikarenakan takut efek sampingnya. Beberapa penelitian yang ada belum ada penelitian yang menyebutkan efek samping dari mengkonsumsi minuman kombinasi asam jawa-kunyit dengan dosis wajar.

\section{KESIMPULAN}

Berdasarkan hasil penelitian eksperimental yang telah dilakukan pada siswi remaja di SMK Farmasi Sekesal Surabaya dapat disimpulkan bahwa ada perbedaan bermakna pada pemberian kedelai (Glycine max) dan kombinasi asam jawa ( $T$. indica) dengan kunyit ( $C$. domestica) terhadap skala nyeri dismenorea. Setelah dilakukan uji Wilcoxon Sign Rank Test dan Mann Whitney U Test, didapatkan ada perbedaan yang signifikan terhadap penurunan skala nyeri yang diberikan kombinasi asam jawa ( $T$. indica) dengan 
kunyit (C. domestica) dan kedelai (G. max) pada remaja di SMK Sekesal Surabaya.

Berdasarkan uraian diatas peneliti dapat menyimpulkan bahwa minuman kedelai ( $\left.\begin{array}{ll}G \text {. } & \text { max }\end{array}\right)$ maupun minuman kombinasi asam jawa (Tamarindus indica) dengan kunyit (C. domestica) dapat menurunkan dismenorea. Tetapi minuman kombinasi asam jawa ( $T$. indica) dengan kunyit $(C$. domestica) lebih menurunkan skala nyeri dismenorea dibandingkan minuman kedelai (G. max) pada siswi remaja di SMK Farmasi Sekesal Surabaya. Penanganan dismenorea dengan minuman kombinasi kunyit asam dapat diterapkan sebagai alternatif pilihan apabila penderita tidak ingin mengkonsumsi obat-obat medis sebagai penghilang nyeri dismenorea.

\section{UCAPAN TERIMA KASIH}

1. Letkol Laut (K) Drs. Amir Agus Said, Apt., M.Kes selaku komandan SMK Farmasi Sekesal Surabaya yang telah memberikan ijin penelitian.

2. Beberapa staf di SMK Farmasi Sekesal Surabaya yang telah membantu dalam pengumpulan data.

3. Siswi SMK Farmasi Sekesal Surabaya yang telah bersedia menjadi responden.

\section{DAFTAR PUSTAKA}

Anindita, A. Y. (2010). Pengaruh Kebiasaan Mengkonsumsi Minuman Kunyit Asam terhadap Keluhan Nyeri Dismenorea pada Remaja Putri di Kotamadya Surakarta. Skripsi; Fakultas Kedokteran Universitas Sebelas Maret, Surakarta.

Anugroho, D \& Ari, W. (2011). Cara Jitu Mengatasi Nyeri Haid. Yogyakarta: Andi Offset.
Astuti, W. P. (2016). Pengaruh Pemberian Vitamin B1 dan Kunyit (Curcuma longa) terhadap Penurunan Derajat Nyeri Dismenore pada Mahasiswa Program Studi Pendidikan Bidan Universitas Airlangga. Skripsi; Fakultas Kedokteran Universitas Airlangga, Surabaya.

Blackburn, J. \& Jane, H. (2014). Keperawatan Medical Bedah (Edisi 8). Singapore: Elsevier.

Budiarti, A. \& Rizta, N. (2015). Efektivitas Pemberian Terapi Susu Kedelai terhadap Penurunan Skala Nyeri Haid (Dismenorea) pada Remaja Putri di Pondok Pesantren Al Jihad Surabaya. Surabaya: Stikes Hang Tuah Surabaya.

Caluwe, Emmy, D. \& Damme, P. V. (2010). Tamarind (Tamarindus indica L): A Review of Traditional Uses, Phytochemistry and Pharmacology. American Chemical Society; 23; 53-83.

Jurenka, J. S. (2009). Anti-Inflamatory Properties of Curcumin, A Major Constituent of Curcuma longa (A Review of Preclinical and Clinical Research). Alternatif Medical Review; 14; 141153.

Marlina, E. (2012). Pengaruh Minuman Kunyit terhadap Tingkat Nyeri Dismenore Primer pada Remaja Putri di SMA Negeri 1 Tanjung Mutiara Kabupaten Agam. Peneltian; Fakultas Keperawatan Universitas Andalas, Padang.

Noorafshan, A. (2012). A Review of Therapeutic Effect of Cucurmin. Current Pharmaceutical Design; 19; 2032-2046.

Smith, R. \& Kaunitz, A. (2015). Primary Dysmenorrhea in Adult Women: Clinical Features and Diagnosis. Alphen aan den Rijn: Wolters Kluwer. 